\title{
MEMBRANOUS STRICTURES OF THE ESOPIAGUS OF OBSCURE ETIOLOGY
}

\section{WILLTAM LERCHE, M.D.}

ST. PAUL, MINN.

The occurrence within a year of three cases of benign cryptogenic stricture of the esophagus has indicated that the condition may be of relatively frequent. occurrence. These strictures have occurred in the cervical part of the esophagus in women, the youngest of whom was 32 , and the other two 67 years of age.

When a middle-ageed or elderly patient complains of difficulty in swallowing, it is apt to be diagnosticated offhand as clue to nervousness or cancer, according to the length of time the trouble has lasted. Ocular inspec-

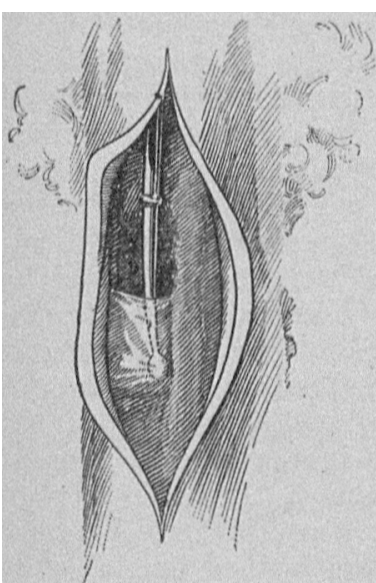

Iig: 1.-The pocket demallstinted by the probe with the incovalble end.

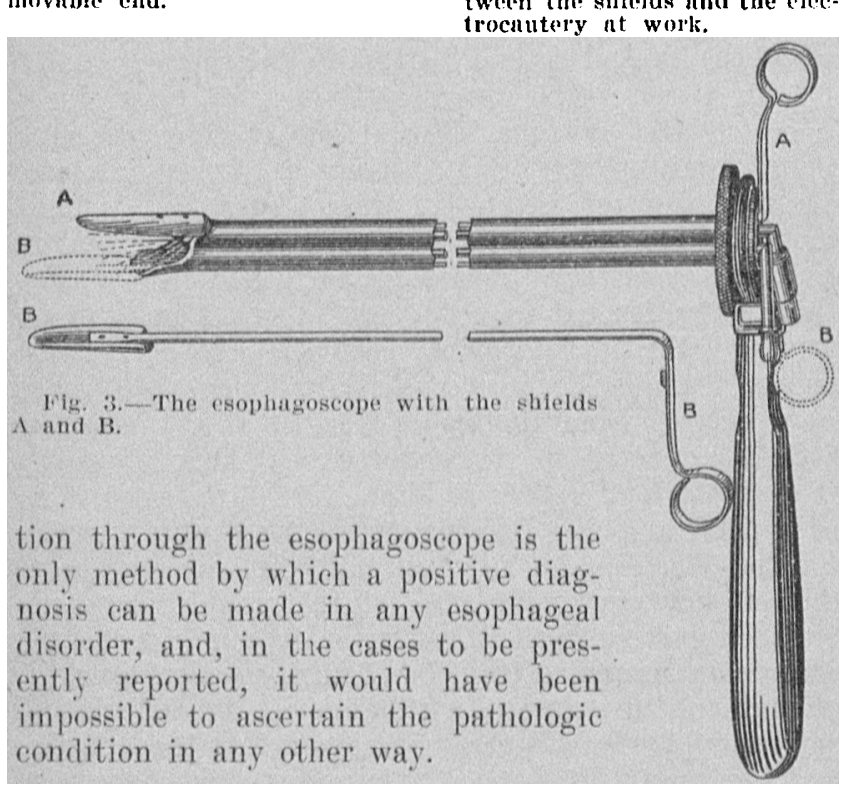

(Ast: 1.-lihe pationt was a woman aged 67 with fifteen "hildren, one still-birtl. The still-birth occurred ut the age of $4: 3$, and was followel hy sepsis from which the patient was ill for several months. More thun eighteen years prior to consultation, she began to liave difliculty in swallowing. For ten ycars she lad bern unable to take solid food; besides liquids she took mostly porridge made of very fille meal.

Coamination.-An obstruction was met $20 \mathrm{~cm}$. from the incisor teeth. A filiform whalchone bougie was introduced through my curved metal guiding tube, and on this a small bougie was passed. When the instrument was passed through the stricture it gave the sensution of tearing through a fairly thick membrane, lisophagoseroy revealed a membranous stricture with un opening posteriorly to the rigint close to the isoplageal wall. A small superficial nlecration was seen just lollow the opening.

Case 2.-Che patient, a woman, uged 67, hind two rhildren. Siloe had mever boen strong, but had been henlthy exeept for protracted and recuring dismbeas at about the age of 3.5 years. Nearly ten yours prior to consultation, the patient began to have dilliculty in swallowing. She chewed her meat und sput it out ngait. Of linte she had been obliged to drink slowly, because otherwise the liquid would be apt to be regurgituted. Cold water would pass better than hot drinks.

Sixamination.-An olsstruction was found $17 \mathrm{~cm}$. from tho incisor teeth. A llexible spiral bourie $11 \mathrm{l}$. could be passed. 13y esophagoscopy a membranous stricture was seen with a imall opening to the left posteriorly, toward which the membran: reconed to be sloping down. The membrane to the right of the opening appeured to be on a sonewhat higher level thun that to the left, thus forming a fold.

Esophagoseopic examination nfter treatment showed rem nunts of the membrane.

CAsE 3.-The pationt, a woman aged 32, had had one child, no miscarriage. About ten yents prior to eonsultation she notieed that she could not swallow onions, ma gradually it becume diflicult to swallow sny solid food. For the last four years she had taken only soft fool and liquids. She had to be very ciareful in eating lecuuse at times even fluids would bu rejected. She frequently gulped up muens.

Lxamination.-An olstruction was encountered $16 \mathrm{~cm}$. from the incisor teetl. An opening was found that admitted an 11 li. flexible bougie. When a somewhat lajger instrument was introduced it guve the sensation of passing through a membrane. Jsophngoscopy revealed a membranous stricture purtly opened. On the posterior wall of the esophagus, somewlut to the right, was seen a superfleial ulceration nnd, at the lower part of this, a diverticulum or pocket, into which the ulcerntion extended, cune into view. The pocket, which measured about $1 \mathrm{~cm}$. in depth, had a thin front wall, apparently consisting of the nucosa only, and conld readily be demonstrated by the aid of uy probe with the morable end (Fig. 1). With the probe thick mucus eould be milked ont of the pocket by stroking its frout wall.

Irealment.-In order to obliterate this poeket it was decided to burn through the front wall. For the protection of the surjounding parts I devised two ivory shields fastened to long brass spring wires, so that after the esophugoseope ${ }^{2}$ was in place the shield $A$ (Fig. 3), conld be introduced througin the esophagoseope into the pocket und attuehed to the short lip of the latter instrument, while the shich 13 in a similar mamer was introduced into the lumen of the esophngus outside the pouket and attachall to the long lip. With the front wall of the pocket thas between the two shields it was burned through with the electrocuntery, under chloroform ancsthetic (Fig. 2). This was followed by the proper after-treatment, and esophagoscopy a few months later revealed a quite normal. looking esophagus.

It is possille that the thin wall of the pocket land originated in the same way as the membranous stricture, but it was situater below the latter. On the other hand, it is possible that the nucosa at the lower edge of the ulceration had become detrelled, and that by constantly lodging mueus and other foreign substances, a pocket had gradually formed.

The latter condition is malogous to one seen by Kussmaulz at necropsy. A man, aged 27 , had a cicatrix from chronic ulcer of pylorus and dilatation of the stomach. Between mucosa and submucosa from the edge of the cicatrix towarl the lesser enrvature there was a $12 \mathrm{~mm}$. deep diverticulum.

1. Jerche, llillam : An Improved Esophagoseope, The Joursal. A. M. A., March 2, 1012, p. 619 .

2. Kussmaul, A.: Libiet de Behundlung der Mngnerwelterung durch cine neue Afethode mittelst der Mugenpumpe, Di:at:ch. Sred. f. k'lu. Med., 1860, vi, 480 . 
The esoplagoscopic exmination of these cases may be facilitated by first introducing the long filiform whalebone bougie, and then the esoplagroscope on this as a guide, in order to have the opening for a landmarks. The probe with a movable end is of the greatest utility here.

'live three pationts whose cases are liere reported are well, and perfectly normal in regard to swallowing.

(i28 Jowry Building.

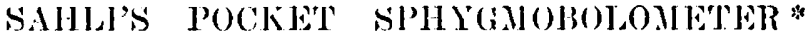 \\ NATHANISL, ]3OWDITCH POTJER, M.b. \\ Assistint l'yofessol of ('lntenl Medicine nt Columbin Cniversity, cellege: of physicfans and sulgeons: Vislting lbystelun to the :Ew York City Joxplial, nut to the French llospital sww rokk}

In orter to estimate the work or the energy of the pulse-wave and so indirectly the strength of the cardiac systole, J'rolessor Sahli has devised and quite recently simplitied a portable and clinically applicable instrument which he calls a porket sphygmobolometer (bolos = a throw); see jllustration.

A suall rubber bay $(D)$ is bound to the radial artery by the cuff' $(J I)$. 'I'his beg is connecterl by small jubber tubing to a 10 c.c. syringe $(G)$, to a horizontal blint manometer ( $E F)$ containing a kerosene index, and to a vertical. throttled mercury mamometer $-(A)$. By means of the srringe the rubber bag is inflated, and the pressure on the contained air jncreased intil the pulsntions of the inclex in the blind manometer rench a maxiImm . The pressure of the air in excess of atmospherie. presenre is then reat on the mercury nanometer. 'Tlue initial volume of air contained in the different parts of the instrument and its connections is given for ench instiument.

If $V=$ volume of the air at atmoxpluerie pressure,

$P^{3}=$ incrosse in pressure in centimeters of mereury,

$13=$ mean barometric pressure (New Fork $=70.4$ en. of mereury)

$(\Delta p)=$ chunge: in pressure, expressed in centimeters of mer. cury, due to pulsutions in the artery (this is obtainer by observing the maximm pulsution of the kelosine index and thun realueing it to centimeters of molemy in the manomuetior), nind

donsity of merenry $=13.6$ gm. per eubie contimeter, thrn the work (IV) done on the contained air by ench pulsewave muy be expressed thus:

$$
\mathrm{W}=\mathrm{V}\left(\frac{\mathrm{B}}{\mathrm{B}+\mathrm{P}}\right)\left(\frac{\mathrm{P}}{\mathrm{B}+\mathrm{P}}\right)(\Delta p) 13.0 \mathrm{gm} . \mathrm{cm}
$$

The alove eguntion is bused on Joyle's or Mariotte's law which stutes that for a given mass of a perfect gas the product of the pressure (per unit aleg) and tive volume is constunt provised the temperature is constant. $\mathrm{p}_{1} \mathrm{v}_{1}=\mathrm{p}_{2} \mathrm{v}_{2}=$ constant. lising the symboly given above we lave

wheriee

$B V=(B+P) V$

$$
\mathbf{v}=\mathbf{v} \frac{\mathbf{B}}{\mathbf{B}+\mathbf{P}}
$$

when $\mathrm{y}$ is the new volume muder pressure.

'The work done in compressing a gas, for very small (hanges in volume, is equal to the product of the applied pressure and the corresponding lecrease in rolume $(p \Delta v)$. If the gas is a perfect gas this work may also be expressed as the product of the volume and the

- Immomstruted at a mering of the Medieal Section of the Now lork Acudemy of Aledleine, iov. 10, 1012. (hange in pressure (v $\Delta p$ ). The total work done in the allove case is

$$
\mathrm{v} \frac{13}{13+1 \mathrm{p}}(\Delta 0)
$$

Jut this work, as was pointed ont by Christen, is dome by the pressure of the pulse and of the atmosphere; hence the part done by the pulse alone is

$$
v(\underset{B}{B}+\mathrm{p})(\triangle \mathrm{n})(\underset{\mathrm{B}+\mathrm{P}}{\mathrm{p}})
$$

If $\mathrm{V}$ is given in culic centimeters and $(\Delta p)$ in centincters of mereury, then to obtain the work in gram centimeter's, the aloore must be multiplied by the density of meteury in granss per cubic centimeter which givers the fimal equation for the work done by a single pulsewave on the air in the instrument.

The value of B may be assumed comstant for any locality, and the volume, $\mathrm{V}$, for any given instrmment is constant. For convenience Prolessol" Salliti has flucrefore calculated at pressures from io to $23 \mathrm{~cm}$. a table of values for

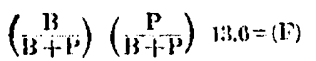

To this I have acted another colmun representing $(\mathrm{F} \times \mathrm{V}$ ) at these pressures, when $V=16.9$ c.c. (the? volume of iny instrument). A similar columm can be? determined for any instrument and remains constint.

$$
W=l \times V \times(\Delta p)
$$

$W=$ IVolk pariomed by ench pulso-wave.

$V=$ Volume of air in instrument No. $13=16.9$ c.c.

\begin{tabular}{|c|c|c|}
\hline l'. & IF. & $l i \times v$. \\
\hline$i$ & .78 & $1: 3.2$ \\
\hline (1) & 92 & $15 . \overline{1}$ \\
\hline 7 & 1.04 & 17.13 \\
\hline$x$ & 1.111 & 111.7 \\
\hline ! & $1.2 x$ & 21.7 \\
\hline 11) & $1.34 !$ & 23.5 \\
\hline 11 & $1.4 !$ & 25.2 \\
\hline 12 & 1.50 & 27.0 \\
\hline ]:3 & $1 .(39)$ & 28.6 \\
\hline 14 & 1.78 & 30.1 \\
\hline & 1.87 & 31,6 \\
\hline $1 \mathrm{i}$ & 1.9 .5 & 32.8 \\
\hline 17 & $\because(1)$ & 34.2 \\
\hline 18 & 2.10 & 35.5 \\
\hline 19 & 2.17 & 30.7 • \\
\hline$\because$ & 2.23 & 37.8 \\
\hline 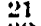 & 2,30 & 38.9 \\
\hline & 2.36 & 39.8 \\
\hline & 2.42 & 40.9 \\
\hline
\end{tabular}

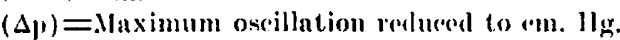

$$
F=\left(\begin{array}{c}
13 \\
B+P+P
\end{array}\right)\left(\begin{array}{c}
p \\
B+1
\end{array}\right) 13.0
$$

$\mathrm{B}=$ Mean harometric pressure $=7$ (i.4 (Now York)

$r^{\prime}=$ Pressure in (.m. Ilg. at muximun axelursion of kelonone index.

'Thus anch estimation requires but one multiplication: $(\Delta) \times,\left(F^{*} \times V^{\prime}\right)$, the figure in the third eolumn, which corresponds to the pressure, P, for maximum exeursions of the kerosene index.

In patients with very high systolic pressures it froquently happens that a larger volume of air is required before the inerease of pressure in the instrument is sulti(ient to induce a maximum pulsation in the blind manometer. In such an event we either substitute in 20) ce. syringe or else cut of the comerting tube from the 10 a.c. syringe with the clamp $(J)$, discomnect syringe, withdraw the piston, recomned syringe, remove ('amp and then exert more pressure. With either procedure the factor $\mathrm{V}$ must be increased by 10 c.e.

The acentacy of any single determination depends mainly on the rending of $(\Delta p)$, errors in the othere terms being negligible in comparison. This involves at rending of the excursions of the kerosene index and a calibration of these excursions in terms of mercury. Com- 